\title{
Gesinsbediening as gesinsverryking: Oor die waarde van 'n sisteembenadering vir 'n pastorale diagnose van gesinsdinamika
}

D J Louw

\section{ABSTRACT}

The enrichment of the family in pastoral ministry: The value of a system approach in a pastoral diagnosis

Within the Reformed tradition, ministry to the family focused mainly on the personal faith of individual members. This was done by means of home visiting. This article proposes a model which attempts to assess the undergirding components and structures which influence intimacy within the family system. A systems model is developed within a hermeneutical understanding of family care. Such a model helps parents to gain insight in the underlying positions of family members. This influences personal identity and developmental issues. In the enrichment of the family, the model is geared towards helping members to shifl their position in order to change the underlying dynamics. A theology for family ministry is developed which can be applied in the assessment of the quality of the interaction of members.

Gesinsbediening is 'n nuwe ontwikkeling op die terrein van gesinspastoraat wat deur die kerk op 'n wetenskaplike en professionele basis ontgin behoort te word. Dit is belangrik dat die kerk 'n visie sal hê oor die moontlikhede van gesinsbediening.

Die rede waarom die kerk gesinsbediening as ' $n$ alternatiewe vorm van bediening naas die tradisionele huisbesoek moet sien, is die volgende: Die kerk is die enigste liggaam of organisasie wat die reg het om lidmate se "private lewe" op aanbod te betree. Kragtens die lidmaatskap en verbondsmatige agtergrond van lidmate se belydenis, is kontak met die gesin binne die milieu van 'n buurt of die huis 'n kleinnood wat die kerk binne 'n gesekulariseerde maatskappy moet benut en ook meer effektief moet ontwikkel.

Die aanname waarmee gewerk word, is dat in 'n gesekulariseerde samelewing binne die proses van verstedeliking en vertegnisering, menseverhoudinge onder druk kom. Daar is min tyd om na mekaar te luister en stories te vertel. Stories oor wat met ons gebeur, dit wat ons ervaar en wat ons oorkom. In hierdie stories skuil daar egter 'n magdom van gegewens 
wat mense kan help om helderheid oor die mees basiese lewensvraag te verkry:

Wat is die sin van my lewe?

Die feit dat na storievertelling en na luister verwys word, beteken dat daar met die aanname gewerk word dat daardie forum om lewenservaringe te deel, naamlik die onderlinge gesprek, besig is om uit die gesigsveld van die gesinslewe te verdwyn. In plaas van die rustige middag- of aandete, het nuusprogramme gekom. Kommunikasie word by wyse van spreke ' $n$ " $M$ Net"-aangeleentheid. Intussen mis ons mekaar. Veral huisgenote wat binne gesinsverband moet saamleef.

Die hele idee agter gesinsbediening is om ' $n$ forum te skep waarbinne gesinslede weer mekaar kan "hoor" en dit wat elke dag tussen hulle gebeur verstaan. Gesinsbediening wil hierdie alledaagse gebeure en onderlinge interaksie koppel aan die gebeure va die evangelie: God se Storie.

Die grondliggende aanname waarmee gewerk word, is eenvoudig. Mense verstaan mekaar nie, veral nie binne gesinsverband nie. Die idee van verstaan sinspeel op 'n diepere behoefte: Mense het 'n behoefte aan intimiteit. Met intimiteit word dan bedoel: Die behoefte om spontaan te ontsluit sonder die angs of onsekerheid om verwerp te word. Gesinsbediening moet hierdie diepere behoefte aan intimiteit help ontsluit en met behulp van die Evangelie verder ontwikkel.

'n Verdere aanname waarmee gewerk word, is dat een van die mees basiese probleme in menseverhoudinge is angs: ons angs vir isolasie en verwerping met die diepere behoefte om in liefde onvoorwaardelik aanvaar te word vir wie jy as mens is (ten spyte van gebreke, tekortkominge, foute en sonde). Hierdie bestaansangs is die kernprobleem waarmee mense worstel. En die mees sinvolle plek, indien nie die enigste nie, waar hierdie angs vir verwerping en behoefte aan onvoorwaardelike aanvaarding sinvol aangespreek kan word, is die huisgesin.

In die lig van hierdie aannames, wil die artikel die volgende hipotese aan die orde stel: Ten einde die vraagstuk van verwerpingsangs binne gesinsverband pastoraal te hanteer, is dit allereers nodig om kriteria te identifiseer aan die hand waarvan 'n pastorale diagnose die aard van die onderlinge interaksie tussen gesinsgenote kan evalueer. Die doel is dan om die "gesinsklimaat", met ander woorde die vlak van aanvaarding en openhartigheid, te peil. 'n Pastorale diagnose wil kyk na die kwaliteit van die onderliggende gesinsinteraksie en dinamika. Die vraag is, hoe? Die antwoord op hierdie vraag behoort gesoek te word in dit wat die sisteem- 
benadering beklemtoon: Die evaluering van gesinslede se posisies binne die gesinsisteem. 'n Dergelike vertrekpunt werk met die volgende aanname van 'n sisteemmodel: "The components do not function according to their 'nature' but according to their position in the network"'. 'n Sisteembenadering beoog dus strukturele gesinsterapie. Dit fokus op prosesse en posisies binne die gesinsisteem deur die strukture wat die onderlinge interaksie bepaal, te verstaan en dienooreenkomstig posisies te wysig (posisieskuiwe). ' $n$ Dergelike benadering lokaliseer "the problem in the structure of the system rather than in the nature of the symptomatic member”2.

As raamwerk vir die toepassing van 'n sisteemmodel vir gesinsbediening, word eers aandag gegee aan die meer algemene vraagstuk van gesinsbediening. Daarna word gekyk na 'n teologiese raamwerk waarbinne 'n sisteemmodel sinvol vir die pastoraat kan funksioneer. In die gedeelte oor die teoretiese uitgangspunte vir gesinsbediening, sal dan die verskillende kriteria geïdentifiseer word wat neerslag kan vind in 'n verrykingsmodel.

\section{DIE DOEL VAN GESINSBEDIENING}

Gesinsbediening wil huisgenote help om:

1.1 mekaar beter te verstaan.

1.2 Hierdie verstaan beteken insig in die verskillende posisies, plekke of houdinge wat gesinslede teenoor mekaar inneem. Gesinsbediening wil lidmate help om die "geheel" van die gesin raak te sien en te verstaan.

1.3 Insig te ontwikkel oor die verbande, kontekste en sisteme waarbinne huisgenote daagliks lewe.

1.4 Dit wil 'n positiewe atmosfeer skep waarbinne die Christelike norm van onvoorwaardelike liefde en aanvaarding binne gesindhede en konstruktiewe gedrag, gestalte kan aanneem.

1.5 Gesinsbediening beoog om die gesin se storie, hulle ervaring van die lewe, so aan God se Storie (die Evangelie) te verbind dat gesinsgenote sinvolle oomblikke sal ontdek wat 'n indruk sal maak op lede se verstaan en ervaring van die waarde van hul lewe (identiteit en selfbeeldontwikkeling).

Kortom kan ons sê dat gesinsbediening reg wil laat geskied aan die belangrike Bybelse gedagte dat gelowiges mekaar moet versorg en 
ondersteun. Ons kan sê dat gesinsbediening binne die huisgesin gestalte wil gee aan Romeine 15:7: "Aanvaar mekaar dan, soos Christus julle ook aanvaar het tot eer van God". Indien hierdie stelreël, wat die basis vorm vir die gemeentelike lewe, nie gestalte vind in die huisgesin nie (God se mini-gemeentetjie op aarde) ${ }^{3}$, sal dit moeilik wees om op sigbare en ervaarbare wyse die kerk se boodskap elders, soos byvoorbeeld in die samelewing, waar te maak. Gesinsbediening moet dus gesien word as 'n poging om die konsep van onderlinge en wedersydse versorging van mekaar, op 'n geloofwaardige wyse gestalte binne die interaksiepatrone van die gesin te laat aanneem.

\section{GESINSBEDIENING TEENOOR HUISBESOEK?}

Gesinsbediening moet beskou word as 'n alternatiewe vorm van bediening en nie as 'n plaasvervanging van die tradisionele huisbesoek nie.

Huisbesoek vandag beteken vier dinge:

2.1 Dit wil met lidmate binne die woonarea kontak maak ten einde 'n vertrouensverhouding te bou.

2.2 Dit wil 'n kommunikasienetwerk tussen die private lewe van die gesin en die liturgiese lewe van die gemeente skep. Daarom dat huisbesoek beskou kan word as die liturgiese verlengstuk van die erediens.

2.3 Dit wil lidmate se spiritualiteit ontwikkel, met ander woorde, dit wil lidmate se bewuswees van God se teenwoordigheid in hulle lewe versterk en lidmate aanmoedig en vermaan om in toewyding aan God te lewe. Daarom dat sentraal in die huisbesoek vrae staan soos: Wat is 'n sinvolle gesprek met God (gebed) en 'n sinvolle luister na God (Bybelbestudering)?

2.4 Dit wil in lidmate se sosiale behoefte vervul, naamlik om met iemand van die gemeente kontak te hê. Hierdie behoefte kan natuurlik verswak des te meer die samelewing gesekulariseer raak.

Die vraag wat nou opduik is: Waar lê die verskil met gesinsbediening?

Ons kan sê dat gesinsbediening 'n variant is van huisbesoek. Terwyl huisbesoek egter meer op die geloof van individuele lidmate binne gesinsverband en gemeenteverband konsentreer, konsentreer gesinsbediening op die dinamika en interaksie van die gesin as geheel. Gesinsbediening is dus 'n meer gefokusde vorm van huisbesoek. Dit fokus heel spesifiek op die aard en karakter van gesinslede se posisies en 
kommunikasiestyle ten einde met behulp van die Christelike eis van naasteliefde 'n atmosfeer van onvoorwaardelike aanvaarding te skep. Gesinsbediening fokus dus die gesin op intimiteit en wil die gesin help om betyds daardie faktore te identifiseer wat sinvolle interaksie belemmer. Gesinsbediening wil dus op die vlak van gesinsbehoeftes voorkomend te werk gaan. Dit wil die gesin help om mekaar nie net beter te verstaan nie, maar ook om die evangelie in verband te bring met dit wat gesinsgenote daagliks van mekaar ervaar.

Die groot vraag is: Hoe? Watter verskillende tipes van gesinsbediening bestaan daar?

\section{VERSKILLENDE TIPES VAN GESINSBEDIENING}

Die opmerking is reeds gemaak dat gesinsbediening 'n variant is van huisbesoek. As variant besit gesinsbediening 'n enger betekenis: Dit wil die interaksiepatrone binne die gesin evalueer en "diagnoseer", dit wil sê, dit wil die gesin help om te evalueer dit wat daagliks tussen hulle plaasvind. Hierdie daaglikse gesinsgebeure wil gesinsbediening met die Christelike boodskap van liefde óf verryk, of verander. Ons kan gesinsbediening noem: Dinamiese gesinsverryking en gesinsontwikkeling.

Daar bestaan egter ook ander vorme van gesinsbediening soos die tradisionele huisbesoek; huweliksbediening waar meer op die man-vrouverhouding gefokus word; ouerbegeleiding waar voorligting en informasie aan ouers deurgegee word oor die begeleiding van kinders rondom hul emosionele, persoonlike en geloofsbehoeftes dwarsdeur die verskeie lewensiklusse van hul ontwikkeling; gesinsterapie waar gefokus word op spesifieke probleme binne gesinsverband; gesinsondersteuningsgroepe waar verskillende gesinne in 'n buurt of wyk aan mekaar gekoppel word met die doel om mekaar by te staan en te ondersteun. Dit is hier waar die bediening aan gesinne binne 'n wyksverband 'n groot rol kan speel. Dan is daar ook nog die moontlikheid van 'n kruis-kulturele bediening waar skakelgesinne uit verskillende kultuurkontekste op sekere tye in mekaar se huise byeenkom en kans gegee word om na mekaar se eie unieke stories te luister. Byvoorbeeld, die storie van die Afrikaner en Christelike onderwys en die storie van mense in agtergeblewe gemeenskappe oor swak gehalte van onderwys en onderwysfasilteite word so vir mekaar "hoorbaar". Op hierdie vlak speel die kerk dan 'n fasiliterende rol ten einde uiteenlopende belangegroepe binne gemeentelike verband nader aan mekaar te bring en konflik voorkomend te hanteer. 'n Laaste vorm van gesinsbediening is waar 'n buurt spesifieke verantwoordelikheid vir die kategetiese onderrig 
aanvaar. Kategese vind plaas sowel in die gesin as in die buurt deur die ouers self of ander ouers. Kategese word dan ten diepste gesien as die geloofsbegeleiding van kinders binne die verbondsgesin.

Die verskillende vorme van gesinsbediening vul mekaar aan. Verskillende vorme van gesinsbediening kan gevolg word na gelang van die eie aard en konteks van die gemeente. Alle vorme van gesinsbediening kan ook nie tegelykertyd aandag geniet nie. Die fokuspunt val in hierdie stuk op gesinsverryking en gesinsontwikkeling omdat die bediening hier die geheel van die gesin en die onderlinge interaksie tussen gesinslede wil verryk met die waarhede van die Evangelie.

Die verskillende vorme van gesinsbediening kan skematies as volg voorgestel word.

\section{VERSKILLENDE VORME VAN GESINSBEDIENING}

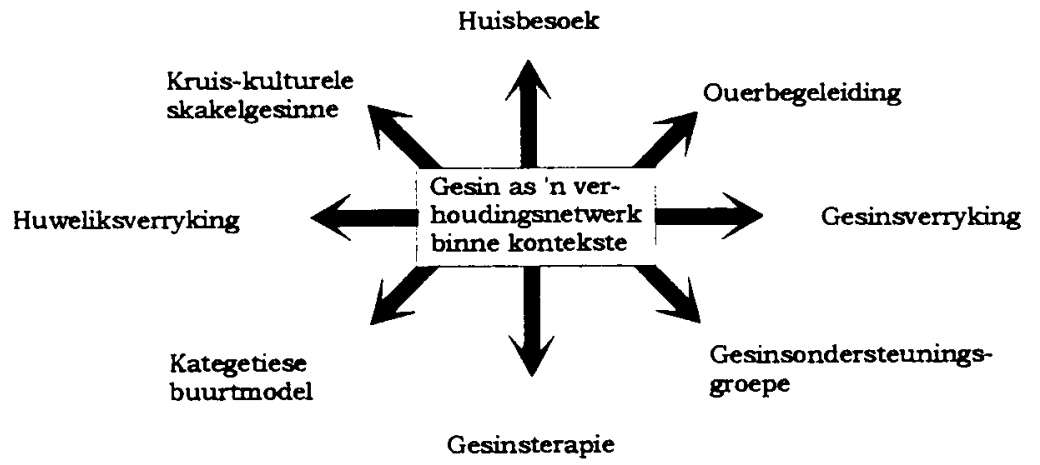

\section{DIE SISTEEMBENADERING EN DIE TEOLOGIESE FAKTOR VAN DIE VERBONDSISTEEM}

Die belangrike vraag wat nou aan die orde gestel moet word, is: Maar wat is die teologiese koherensiefaktor vir al hierdie verskillende vorme van bedieninge?

In terme van ' $n$ sisteembenadering, word met die aanname gewerk dat met 'n "sisteem" bedoel word: Die onderlinge netwerk van interaksieprosesse en struktuurkomponente wat in onderlinge wisselwerking funksioneer en mense se posisies, disposisies (houding) en ervaring van identiteit wesenlik beïnvloed. Sisteemdenke werk nie met liniêre ${ }^{4}$ of veelvuldige oorsaaklikheid nie, maar met die nie-liniêre beginsel van wederkerige 
interafhanklikheid; die dinamiese organiserende beginsel van be"̈vloeding $^{5}$, asook die verbindingsfaktor van relasionaliteit met behoud van uniekheid (differensiasie binne interrelasionaliteit). 'n Sisteemmodel werk dus met die eenvoudige en basiese beginsel van 'n komplekse web van menseverhoudinge. "As humans, we live in a complex web of relationships with ourself, others, our natural and social context, and the spiritual dimension of life"6. Die veronderstelling is: Mense bestaan binne sosiale en emosionele sisteme wat hul identiteit wesenlik beïnvloed.

Die teologiese variant vir so 'n sisteem van interrelasionaliteit en verweefde skakeling (interconnectedness) is die verbond. "We agree that the concept of covenant is the fundamental and essential element in developing a theology of the family" 7 .

'n Verbondsparadigma ${ }^{8}$ as teologiese basisteorie vir gesinsbediening bestaan uit die volgende vier dinamiese komponente: Die bindende komponent van uitverkiesing en roeping deur God; die verlossende komponent van heil en genade; die kennis- en gesagskomponent van wysheid en die intimiteitskomponent van liefde (agape). Dit beteken dat 'n verbondsisteem bepaal word deur die volgende teologiese pole.

* Uitverkiesing. Uitverkiesing verwys na die feit dat ouerskap nie bloot ' $n$ biologiese aangeleentheid is nie. Dit is nie die seleksiebeginsel (ek kies 'n maat op die basis van voorkeure en besluit om kinders te hê) wat ouerskap ten diepste bepaal nie, maar die eleksie-beginsel ${ }^{9}$. Hierdie teologiese aanname beteken: Ek is deur die geloof daartoe geroep (vocation) om 'n ouer vir hierdie kind te wees. Vandaar die waardevolle opmerking deur Anderson en Guernsey: "The second significance of covenant as a paradigm of family is that selection is affirmed and sustained by election" 10 .

Die bipolariteit van eleksie-seleksie bring in ' $n$ verbondsisteem vir gesinsbediening die faktor van binding (vastigheid), toewyding (commitment) en kontinuïteit. 'n Mens kan sê, eleksie as 'n verwysing na die trou van God is die teologiese kohesiefaktor vir gesinsdinamika. En hierdie trou van die Here word bevestig deur die doop. Eleksie ${ }^{11}$ en doop vorm dus die strukturele gegewe vir 'n verbondsisteem.

Genade. Genade verwys na die faktor van bevryding en verlossing. Genade werk met die beginsel dat God ons aanneem as sy kinders, nie op grond van kwaliteite nie, maar op grond van sy barmhartigheid. Die perspektief van genade bring mee dat gesinslede mekaar 
nie evalueer in terme van foute/tekortkominge en sonde nie (kritiese veroordeling), maar mekaar waardeer in terme van moontlikhede (daardie kwaliteite wat op grond van die verlossing in Christus in gelowiges as gawes [charisma] van die Gees belê is). Genade verteenwoordig dan die dimensie van openheid, soepelheid en aanpasbaarheid binne die gesinsisteem.

Wysheid. Wysheid verteenwoordig die unieke faktor van gesag en kennis. Kennis is dan gerig op insig; daardie onderskeidingsvermoë waardeur gesinslede mekaar ken in terme van die genadebeginsel. Ouers se gesag setel dan nie in hul status en hiërargiese posisie nie, maar in hul aanstelling deur God om die verhaal van die verlossing (die eksodustradisie) van een geslag tot die ander oor te dra (Ps 68:3-6). Hierdie gesagsfaktor en ken-beginsel beteken prakties in 'n verbondsisteem dat gesinslede deur hul roeping (eleksie) en deur hul openheid (genade) mekaar deur die wysheid dien (diakonia). Die diensfaktor veroorsaak dat die gesin 'n mini-gemeentetjie is waardeur God se Vaderskap ${ }^{12}$ (vgl Ps 103:13) tot uitdrukking kom. Die uitwerking van hierdie diensfaktor op die gesinsisteem in 'n gesinsbedieningsmodel is dat die gesin 'n liturgiese leefruimte is waarbinne ouerskap 'n priesterlike dimensie van diens verkry'13.

Liefde $^{14}$. Liefde verteenwoordig die faktor van samehorigheid en intimiteit $^{15}$. Met "intimiteit" word dan bedoel: Om mekaar onvoorwaardelik te aanvaar sonder die angs vir verwerping. Intimiteit is wesenlik dit wat gesinslede saamsnoer en wat 'n atmosfeer van nabyheid en behoort aan die gesinsisteem verleen. Die samehorigheid wat die Christelike liefde skep, verswelg egter nie die individu nie, maar is daarop gemik om individualiteit, uniekheid en identiteit te ontwikkel. Liefde skep ook 'n etiese faktor van wedersydse verantwoordelikheid vir mekaar, asook 'n pastorale faktor: Wedersydse sorg, omgee en hulp aan mekaar. Dit is deur die liefde dat God se minigemeentetjie mekaar in alles ondersteun, versorg en troos (koinonia). Liefde skep 'n atmosfeer van geborgenheid en koestering. 
Die vier teologiese komponente van 'n dinamiese gesinsisteem/verbondsisteem kan soos volg voorgestel word:

(4)

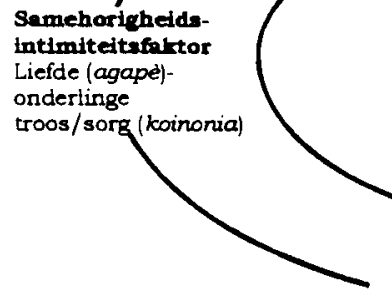

(1) Kohestefaktor (kontraktueel: doop) Eleksie-Seleksie

(3) Geun en Kenfiltor

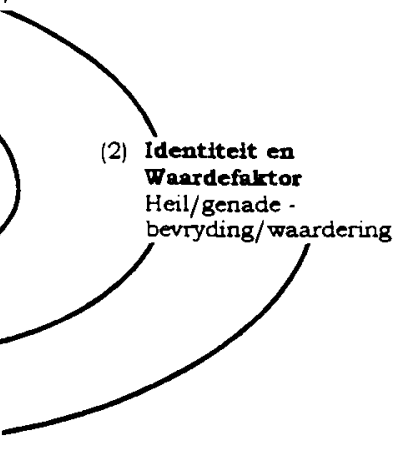

Die vraag kan nou gestel word: Maar wat is die praktiese en bedieningsimplikasie van 'n teologiese benadering vir 'n sisteemmodel? Om hierdie vraag te beantwoord, moet gekyk word na daardie komponente wat wesenlik die aard van 'n sisteemmodel bepaal. Die veronderstelling is dat wanneer hierdie komponente geïdentifiseer en ouers en kinders daaromtrent geëvalueer kan word, die teologiese faktore aangewend kan word om gesinslede se houding en gesindheid te verander ten einde die gesinsatmosfeer te wysig.

\section{TEORETIESE UITGANGSPUNT VAN GESINSBEDIENING: GESINSVERRYKING EN GESINSONTWIKKELING 16}

Gesinsbediening as gesinsverryking en gesinsontwikkeling fokus minder op net inhoude en feite en meer op prosesse, houdinge, en gesindhede binne die gesin. Ons sou kan sê dat gesinsbediening fokus op gesinslede se posisies ${ }^{17}$ wat hulle binne die gesin inneem. Hierdie posisies word deur die volgende faktore beïnvloed:

5.1 Houding en emosies. Elke gesinslid se houding word bepaal deur 'n groep emosies wat hetsy negatief (destruktief) of positief (konstruktief) kan wees. 'n Egosentriese posisie is dikwels negatief 
terwyl 'n altruïstiese posisie op ander lede in die gesin fokus en 'n konstruktiewe uitwerking besit.

5.2 Persepsies. Hoe gesinslede mekaar sien, bepaal hul optrede teenoor mekaar. Stereotipes en etikettering werk hier dikwels negatief op die gesinsinteraksie in. Byvoorbeeld, 'n gedurige opmerking soos: "Jy is lui, jy is selfsugtig, jy is stout, jy is onverantwoordelik", dra by tot die ontstaan van negatiewe persepsies.

5.3 Rolverwagtings. Die verwagtings wat gesinslede van mekaar het, bepaal deurslaggewend die karakter van interaksieprosesse en style van kommunikasie. Faktore soos "die ideale ouer" of die "ideale kind" (modelkind) speel byvoorbeeld hier 'n rol.

5.4 Behoeftes. Gesinslede se basiese behoeftes aan erkenning, waardering en aanvaarding bepaal die onderlinge interaksie. Daar is ook nog fisieke behoeftes soos voeding en behuising, asook behoeftes aan veiligheid en beskerming.

5.5 Familietradisies en die familie van oorsprong. Gebeure in die familie en die rol van grootouers asook dié se ouers werk deur na die bestaande gesin. Ouers se binding en kontak met hulle ouers is ' $\mathrm{n}$ indirekte maar dikwels ook direkte faktor binne gesinsinteraksieprosesse.

5.6 Gesindheid. Die twee basiese gesindhede van weerstand/vyandigheid/haat en liefde (onvoorwaardelike aanvaarding) bepaal die gesinsdinamika deurslaggewend.

5.7 Waardes en norme. Binne elke gesin bestaan daar sekere gebruike, gewoontes en tradisies wat gekoppel is aan norme en waardes. Kultuurkonteks speel hier 'n groot rol.

5.8 Gedragsreaksies. Gesinslede is voortdurend besig om op mekaar te reageer. Optrede binne gesinsverband is dikwels 'n reaksie op wat gesinslede van mekaar ervaar en sê en met mekaar doen. Die gedragsreaksie kan of onttrekkend (dissosiasie) of bemagtigend/ondersteunend (assosiasie) wees.

5.9 Opvoedingstyle. Opvoedingstyle geskied gewoonlik in die volgende teenoorgestelde pare: Dominerend (oorheersend) - permissief (toeskietlik); begrip - kritiek. Die pare is wisselend en kom nie suiwer voor nie. Dit wissel dus na gelang van omstandighede en die fases waardeur die gesin beweeg.

5.10 Gesinstrukture. Op 'n emosionele vlak is daar die wisselende emosionele struktuuras van afstand - nabyheid. Op die regulatiewe gesagsas is daar die wisselende dinamika van: Kontrole (dissipline) en selfstandigheid (losmaking). Hierdie gesinstrukture wissel ook na 
gelang van die fase waarin die gesin verkeer (peuter, kleuter, skoolgaande kind, puberteit, adolessensie, verlating van die ouerhuis).

5.11 Lewensbeskouing. Binne gesinne is daar 'n bepaalde "filosofie" oor die lewe aanwesig. Gesinne in 'n welvaartskultuur gaan meer georiënteer wees aan die prestasiedruk van "achievement ethics" as gesinne binne 'n armoedekultuur wat meer georiënteer is aan die basiese behoeftes van oorlewing.

5.12 Geloofsoortuigings. Die geloofsvolwassenheid van gesinslede speel 'n groot rol in die kommunikasie van geloofswaarhede. Gesinslede se siening en verstaan van God bepaal direk of indirek die interaksieprosesse binne die gesin. Byvoorbeeld, die siening van God as Regter gaan 'n meer streng en dissiplinêre houding van afstand tot gevolg hê, terwyl die siening van God as Vriend 'n meer ontspanne en gemoedelike houding van betrokkenheid tot gevolg het.

Indien gesinsbediening, as gesinsverryking, op bogenoemde komponente wil konsentreer en dit met die Evangelie wil verryk, gaan atmosfeer 'n groot rol speel. Gesinsverryking wil dus die atmosfeer van die gesin beïnvloed en aldus verander vanaf 'n negatiewe, kritiese atmosfeer, wat dikwels stuit op weerstand en vyandigheid, tot 'n positiewe atmosfeer van liefde, begrip en aanvaarding, wat dan hopelik intimiteit sal ontwikkel.

\section{BASIESE STRUKTURE EN POSISIES BINNE DIE GESINSISTEEM}

Gesinsverryking werk met die basiese aanname dat die emosionele struktuuras van afstand - nabyheid en gesagstruktuuras van dissipline selfstandigheid die dinamiese pole vorm waarbinne die interaksieprosesse binne die gesin voltrek word. Binne hierdie prosesse is daar dan vier basiese posisies wat gesinslede teenoor mekaar kan inneem: Ondersteuning/bemagtiging (A), beskerming/vertroeteling (B), oorheersing (C) en verwaarlosing/onttrekking (D). Hierdie vier basiese posisies skuif na gelang van die graad en gehalte van intimiteit (= die vermoë en bereidheid om te ontsluit binne die atmosfeer van 'n onvoorwaardelike aanvaarding van mekaar sonder die angs of onsekerheid vir verwerping).

Wat gesinsverryking dus wil bereik, is tweërlei:

* Dit wil gesinslede help om hul posisies binne die interaksiepatrone van die gesin te ontdek en te verstaan. Die hipotese waarmee 
gesinsverryking werk, is dat 'n verstaan van hierdie posisies verandering binne die gesin as geheel tot gevolg kan hê.

* Dit wil die Christelike verstaan van liefde (opoffering, diens, onvoorwaardelike aanvaarding) gebruik om die atmosfeer van ' $n$ gesin sodanig te beïnvloed dat gesinslede besluite sal neem oor, en ook verantwoordelikheid sal aanvaar vir posisieskuiwe.

Gesinsverryking wil dus nie soseer gesinslede se persoonlikheid en karakter verander nie ${ }^{18}$. Dit wil gesinslede se geloofsoortuiging en waardesisteem aanwend om sinvolle posisieskuiwe te ondergaan. Die impak van gesinsverryking is dus verandering in gesinslede se posisies via 'n gesindheidsverandering.

Ten einde 'n posisieskuif te kan maak, moet lede van die gesin, sowel as die totale gesin, gehelp word om die interaksieprosesse binne die gesin self te evalueer. Dit is op so 'n evaluering of assessering dat gesinsbediening as gesinsverryking ingestel is. (Vandaar die diagnostiese aard en karakter van die voorgestelde model vir gesinsverryking).

\section{HOE? DIE SOEKE NA 'N METODE}

Twee metodes is hier op die spel. Hul kan genoem word:

7.1 'n dieptemetode. Dit is 'n metode wat die gesin wil help om hulself te verstaan teen die agtergrond van hul familiegeskiedenis en familiestorie. Hier kan die pastor gebruik maak van 'n genogram. 'n Genogram is 'n grafiese voorstelling van belangrike gebeure binne die geskiedenis of storie van die gesin en die familie19.

7.2 'n dwarssnitmetode. Dit is 'n metode wat die gesin se ervaring van mekaar self in die dwarssnit van bestaande strukture wil evalueer. Twee basiese dwarssnitstrukture is reeds genoem: Die emosionele ervarings as (afstand - nabyheid) en die strukturele gesag-as (dissipline - selfstandigheid).

Die dwarssnitmetode hou rekening met die feit dat gesinslede se vermoë om aan te pas en te verander deurslaggewend is vir die eventuele "gesondheid van die gesin". Rigiditeit op enige punt van die gesinsinteraksie rem die spontaneïteit en funksionaliteit van die interaksieprosesse. Aanpasbaarheid en soepelheid as 'n aanduiding van volwassenheid bevorder die interaksieprossesse positief. 
Die model wat vir gesinsverryking voorgestel word, kan die dinamiese insig en intimiteitsmodel genoem word. Hierdie model bestaan uit die volgende aspekte en kan grafies, soos op die onderstaande diagram, voorgestel word. Vir die doel van hierdie artikel sal slegs op 'n evalueringsvorm vir ouers gekonsentreer word ten einde die gebruik van so 'n vorm vir 'n assesseringsmodel in gesinsbediening te illustreer.

Die vier dinamiese kwadrante van die ouer-kind interaksie: Afstand nabyheid; kontrole/dissipline - losmaking met hulle positiewe fokuspunte wat tegelykertyd die doelwit van die ouer-kindinteraksie is: Intimiteit en volwassenheid, het vier benaderinge tot gevolg. Hierdie vier benaderinge beskryf basies vier rolfunksies wat ouers binne die houdings- en gesagsdinamika kan aanneem:

(1) Die ondersteunende benadering waarin die ouer 'n sterk rolmodel (doen-en leeffunksie) vir die kind is (ONDERSTEUNING).

(2) Die beskermende benadering waarin die ouer optree as kampvegter en beskermheer vir die kind se belange (BESKERMING).

(3) Die dissiplinêre benadering waarin die ouer leiding gee. Hierdie benadering kan maklik as voorskriftelik (dominerend) geïnterpreteer word en tot rigiede (onbuigsame) optrede en 'n wettiese model aanleiding gee (OORHEERSING/OUTORITêR).

(4) Die afskeep- en onttrekkingsbenadering waarin die ouer onverskillig optree en die kind maklik kan of ignoreer of verwerp. Hierdie benadering kom neer op kinderverwaarlosing. Die verwaarlosing word meer emosioneel verstaan binne die vlak van 'n ervaring van 'n negatiewe identiteit en waardeloosheid (VERWAARLOSING).

(3) en (4) lê in die negatiewe sone van die kwadrante. Daar kan met hö̈ waarskynlikheid aanvaar word dat 'n persoon wat emosionele verwaarlosing ervaar, 'n hoë behoefte het aan beskerming (die teenoorgestelde punt van die verwaarlosingsone); 'n persoon wat binne die voorskriftelike en outoritêre sone val, het weer 'n hoê behoefte aan ondersteuning (die teenoorgestelde punt van die outoritêre sone).

\subsection{Doelwit van opvoeding binne die insig-/intimiteitsmodel}

Dit is om die kind binne (a) ' $n$ warm atmosfeer van liefde en intimiteit te laat ontwikkel tot (b) 'n volwasse persoon wat op 'n selfstandige wyse keuses kan makk, asook (c) 'n spirituele persoon wat binne die 
teenwoordigheid van God in geloof die belofte, "Ek sal vir jou 'n God wees", positief toeëien.

\subsection{Strukture van kwadrant}

Die lynstrukture van die kwadrant met sy houdingsdinamika (afstand nabyheid) en sy gesagsdinamika (kontrole - losmaking) word deurslaggewend bepaal deur die gehalte van die houding (die kwaliteit van liefde) en die gehalte van gesag (die inhoud van wysheid) ${ }^{20}$.

Ten einde die interaksie tussen ouer en kind te evalueer en te kyk na die gehalte van die houdingsdinamika en die gesagsdinamika, kan die ouer van die volgende evalueringsvorm gebruik maak. Afhangende van die verband tussen die kontrole en die losmaking en die mate van intimiteit en samesyn/saamhorigheid, gaan die aanpasbaarheid van die ouer wissel. Intimiteit wat fokus op losmaking het 'n hoë aanpasbaarheid. Intimiteit wat fokus op kontrole het 'n lae aanpasbaarheid.

\section{DIAGRAM: OUER-KIND-INTERAKSIE}

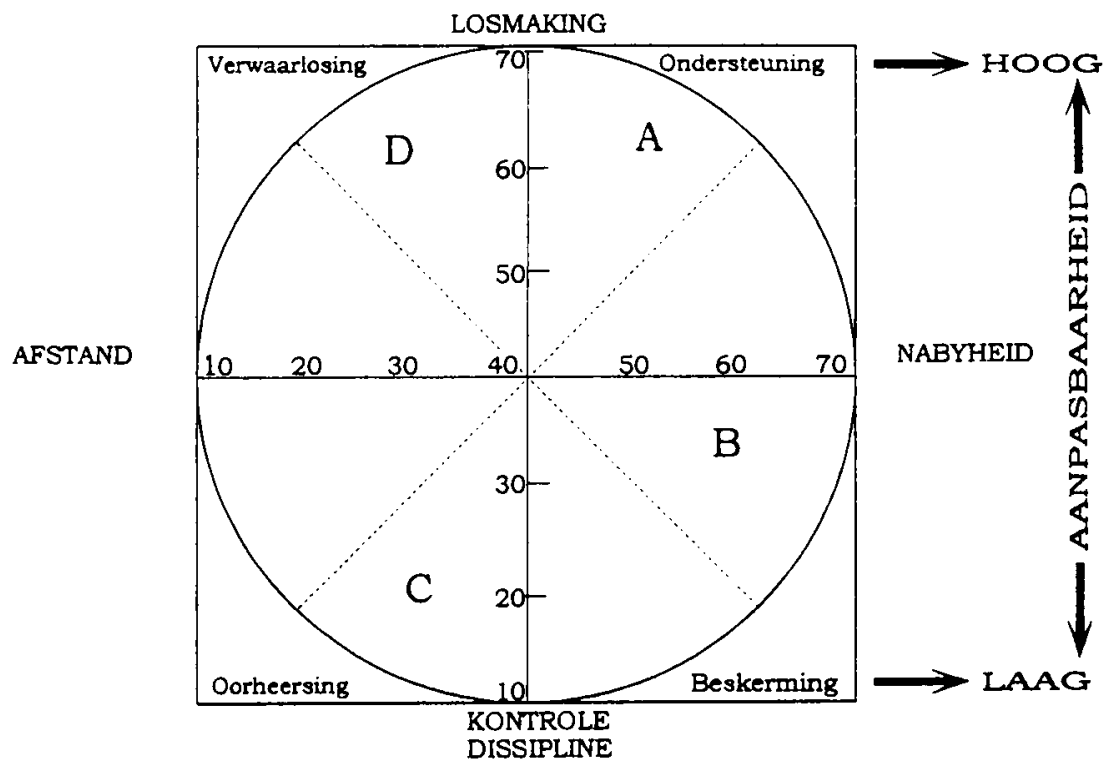

8.3 Opdrag: Beantwoord die volgende stellings en evalueer elkeen deur van die volgende responskeuses gebruik te mak en 'n syferwaarde aan jou betrokke respons toe te ken. Probeer om al die kinders saam in gedagte te hou en moenie op 'n enkele kind fokus nie. Indien die situasie te moeilik 
is, moet die stellings op elke kind afsonderlik toegepas word en verskillende evaluerings vir elke kind gedoen word.

\section{(A) STELLING (VIR OUERS)}

Opmerking: Lees kind as kinders (kind/ers)

\begin{tabular}{|l|l|l|l|l|}
\hline 1 & \multicolumn{1}{|c|}{2} & \multicolumn{1}{|c|}{3} & \multicolumn{1}{c|}{5} \\
\hline $\begin{array}{l}\text { Stem heeltemal } \\
\text { saam }\end{array}$ & $\begin{array}{l}\text { Stem gedeel- } \\
\text { telik saam }\end{array}$ & $\begin{array}{l}\text { Onseker, nog nie } \\
\text { daaroor gedink nie of } \\
\text { spesifiek daar-van } \\
\text { bewus nie }\end{array}$ & $\begin{array}{l}\text { Stem nie heel- } \\
\text { temal saam nie }\end{array}$ & $\begin{array}{l}\text { Stem beslis } \\
\text { nie saam nie }\end{array}$ \\
\hline
\end{tabular}

I Ek en my kind/ers verskil heelwat, gevollik bots ons

2 Om werklik in my kind se doen en late belang te stel, is vir my baie moeilik omdat ek baie besig is

3 My kinders irriteer my dikwels, veral as ek moeg en gespanne is sodat ek maklik my humeur verloor

$4 \mathrm{Ek}$ is onbeholpe met die kinders en voel ongemaklik en onseker in hul teenwoordigheid

5 Daar is min dinge wat ek saam met my kind kan doen

6 Ek beskik oor min tyd om werklik aan die kinders aandag te gee

7 Dit is vir my moeilik om my kinder/ers onvoorwaardelik te aanvaar

8 Ek betrap myself dat ek dikwels baie krities teenoor my kind/ers reageer en sterk van hul foute en tekortkominge bewus is

9 In 'n konflik tree ek negatief op en is geneig om my kind se persoon op 'n afbrekende wyse aan te val

10 Die feit dat God vir my kind by die doop "Ja" ges" het ("Ek sal vir jou 'n God wees") speel nie 'n direkte rol in my opvoeding nie

11 Dit is vir my moeilik om eerlik en opreg waardering vir my kind se sterk punte te gee

12 Ek is versigtig om te maklik vergewensgesind op te tree

13 Die Here verwag van my om kinders te verander en te verbeter

14 Ten einde ' $n$ kind se vertroue te wen, is dit nodig om die kind soms te bederf TOTA A L

- Skryf nou die totaal in op die horisontale as (vgl diagram).

ISSN 0257-8891 = SKRIF EN KERK Jrg 20(1) 1999 
(B) STELLINGS (VIR OUERS)

\begin{tabular}{|c|c|c|c|c|}
\hline 1 & 2 & \multicolumn{1}{|c|}{3} & \multicolumn{1}{c|}{5} \\
\hline $\begin{array}{l}\text { Stem heeltemal } \\
\text { saam }\end{array}$ & $\begin{array}{l}\text { Stem gedeel- } \\
\text { telik saam }\end{array}$ & $\begin{array}{l}\text { Onseker, nog nie daar- } \\
\text { oor gedink nie of spe- } \\
\text { sifiek daarvan bewus } \\
\text { nie }\end{array}$ & $\begin{array}{l}\text { Stem nie heel- } \\
\text { temal saam nie }\end{array}$ & $\begin{array}{l}\text { Stem beslis nie } \\
\text { saam nie }\end{array}$ \\
\hline
\end{tabular}

1 As ek onseker is oor reg/verkeerd, sal ek nie sommer my kind die voordeel van die twyfel gee nie

2 Dit is vir my belangrik om voortdurend te weet waar my kind is en wat hy/sy doen, daarom kontroleer ek gereeld

3 in Ouer behoort self belangrike besluite vir sy kind te neem om sodoende sy/haar belange te beskerm

4 Ek doen liewer self iets as om 'n opdrag aan my kind te gee met die risiko om later alles weer oor te moet doen

5 Dit is vir my belangrik dat die kinders presies sal maak soos wat die huisreëls dit voorskryf. Ek venvag stiptelikheid en onmiddellike gehoorsaamheid

6 Soos wat die Here ' $n$ God van orde is, moet ek streng en baie beslis optree

7 As ek my vir die kinders vererg, gebeur dit soms dat ek in 'n oomblik van woede die kind sommer 'n dwarsklap gee

8 Die tugmaatreel met die mees effektiewe resultate is lyfstraf

9 Dissipline-maatreèls moet absoluut eerbiedig word en is afdwingbaar

10 Gehoorsaamheid beteken dat die kinders nie sal probeer om ' $n$ woord in te kry en met verduidelikings vorendag te kom nie

11 in Mens moenie sommer toegee aan kinders net omdat hulle spyt en hartseer is nie

12 Ten einde ouerlike gesag te handhaaf, is dit nodig om op ' $n$ harde toon en streng met die kinders te praat

13 Ek hou nie daarvan dat die kinders uitslaap en by maats gaan kuier nie. Hulle moet liewer hul maats huis toe bring

14 Dit is vir my belangrik om dinge vir my kind eers goed te keur, soos videos wat gekyk word, sokkie-geleenthede en vriende/vriendinne

TOT A A L

- Skryf nou die totaal in op die vertikale as (vgl diagram). 
Verleng nou die plek van die puntetotaal op die vertikale as, asook die plek van die puntetotaal op die horisontale as. Die snypunt sal 'n aanduiding wees van die posisie en rol wat die ouer binne die dinamika van die houdings- en gesagsinteraksie inneem.

Ouers kan mekaar op elke stelling apart evalueer en dan hulle evaluerings ten opsigte van mekaar vergelyk en bespreek. Hierdie evaluering kan ouers help om 'n noukeurige evaluering van hul style en posisies te maak. Dit kan hulle ook help om byvoorbeeld deur die kleuterfase na die adolessente- en lanseerfase, te verander. Terwyl die kleuterfase meer kontrole verg, verg die adolessentefase meer losmaking met die oog op die ontwikkeling van outonomie en selfstandigheid.

Die evaluering help ouers om bewus te raak van die feit dat waardes en godsdienstige oortuigings ' $n$ belangrike rol in die interaksieproses tussen ouer en kind speel.

\section{HOE MOET DIE GEGEWENS HANTEER WORD?}

Die belangrike pastorale vraag is nou: Wat moet met die gegewens gemaak word?

Die eerste antwoord is: Niks! Daarmee word bedoel dat indien daar saam met die gesin deur middel van die evalueringsvorm an die interaksieprosesse aandag gegee is, sal die prosesse self ervarings vrystel wat vir die gesinslede belangrik is. Die verryking laat dus gesinslede mekaar opnuut ervaar en dit is al op sigself een van die belangrikste gebeure in die gesin!

Op 'n tweede vlak kan die gegewens gebruik word om gesinslede met mekaar te laat gesels. Wanneer die gesinslede verplig word om oor elke opmerking op die vorm met mekaar te gesels, word 'n kommunikasieproses in werking gestel. Met ander woorde, dieptekommunikasie word bevorder.

Op 'n derde vlak gee dit die pastor die kans om die Evangelie konkreet aan die gesin te bedien. $\mathrm{Na}$ 'n bepaling van wat elke ouer se posisie is, moet die ouer nou besluit of dit 'n posisie is wat die teologiese konsepte van genade, vergifnis, versoening, wysheid en onvoorwaardelike liefde effektief aan die kind kommunikeer. Indien die ouer se posisie in die $\mathrm{C} / \mathrm{D}$ kwadrante val, kan die pastor in die geval van gelowige ouers, die ouers begelei tot belangrike posisieskuiwe. Indien die posisies in die A/B kwadrante val, kan die teologiese komponente gebruik word as motiverende, inspirerende en bemagtigende geloofsinhoude vir die verbondsouer se daaglikse opvoedingstaak. Posisieskuiwe vind plaas na die teenoorgestelde 
kwadrant en dan na die naasliggende kwadrant. Posisie $C$ skuif dus na kwadrant A en dan na B. Posisie D skuif eers na B en dan na A.

Die aanname wat gemaak word, is dat mense moeilik vanself hul houding verander en gewillig is om posisieskuiwe te maak. Die verdere aanname is dat sinvolle posisieskuiwe slegs gedoen word as mense bereid is om hulle met 'n positiewe waarde te identifiseer en dan te besluit om 'n posisieskuif te maak. Die pastor kan nou die gawes van die Gees (Gal $5: 22$ ) gebruik om ouers te motiveer en te beïnvloed om sinvolle posisieskuiwe te maak. Slegs op so 'n wyse kan die negatiewe gesinsatmosfeer (weerstand/vyandigheid) gewysig word in die rigting van 'n positiewe gesinsatmosfeer (warmte en intimiteit). Die eis van die Christelike liefde speel in hierdie pastorale kommunikasieproses 'n deurslaggewende rol. Onder 'n Christelike interpretasie van liefde word dan verstaan:

* Opoffering sonder vergoeding

* Diens sonder bybedoeling (m a $\mathrm{w}$ die selfsugtige vraag: Watter voordeel hou dit vir my in?)

* Weggee sonder wins

* Aanvaarding sonder voorwaarde

* Vergifnis sonder boekhouding (onthou die verlede)

* Versoening sonder parool (hou iemand dop totdat dit weer gebeur).

Die hele bedoeling van die verrykingsmodel is om die pastor te help om die Christelike geloof nie abstrak te kommunikeer nie, maar om gelowige ouers te help om hulle geloof in Christus se genade deel te laat word van die daaglikse gesinsinteraksie- en kommunikasieproses. Dit is slegs moontlik as ouers en kinders presies weet wat elke dag tussen hulle gebeur. En dit is wat gesinsverryking wil bereik. Dit wil die daaglikse gebeure van die gesin verryk met die waarheid van die Christelike liefde. Op so 'n wyse word die hele idee van ' $n$ verbondsouer en 'n verbondskind gekonkretiseer en maak die Christelike geloof sin uit.

\section{NOTAS:}

1 E H Friedman, Generation to generation: Family process in church and synagogue, New York/London 1985, 15.

2 Friedman, $a w, 19$.

3 S C Barton, "Living as families in the light of the New Testament", Interpretation (Apr 1998), 132: “...we cannot talk about what it means to be a family from a scriptural point of view without also asking what it means to be a church". 
R S Anderson \& D B Guernsey, On being family: A social theology of the family, Grand Rapids 1985, 11: "Thus a systemic rather than a linear assumption leads to an emphasis upon the patterns of relationship between and among the members of a system instead of an emphasis upon identifying an ultimate cause".

$5 \quad$ Vergelyk Friedman, $a w, 14-16$.

6 D R Bardill, The relational systems model for family therapy: Living in the four realities, New York/London 1997, 2.

7 J O Balswick \& J K Balswick, The family: A Christian perspective on the contemporary home, Grand Rapids 21990, 20. Balswic \& Balswick, a w, 21, aanvaar die volgende nie-liniêre fases as deel van so 'n teologiese uitgangspunt vir die gesin: "covenant, grace, empowering, and intimacy. We further suggest that family relationships will either be dynamic and maturing, or stagnant and dying".

8 Vergelyk Anderson \& Guernsey, $a w, 40-41,46-48$.

9 Oor die verband tussen 'n pastorale eleksie en antropologie, sien D J Louw, $A$ pastoral hermeneutics of care and encounter: $A$ theological design for a basic theory, anthropology, method and therapy, Kaapstad 1998, 145-153.

10 Anderson \& Guernsey, $a w, 41$.

11 J A Dearman, "The family in the Old Testament", Interpretation (Apr 1998), 120: "Election by God does not mean moral superiority but the privilege of divine service".

12 Anderson \& Guernsey, $a w, 61$ : "Theologically, parenting has its antecedent in the Old Testament concept of the Fatherhood of God".

13 Sien D J Louw, Gesinsverryking: Riglyne vir groei en kommunikasie, Pretoria/Kaapstad 1989, 42-62.

14 Anderson \& Guernsey, $a w, 22:$ "As we have already noted, the actual structure of this 'inner logic' of social relation unique to the formation of the family is grounded in the intentionality and practice of love".

15 Binne 'n Amerikaanse paradigma word liefde en intimiteit in gesinsverband minder verstaan in terme van opoffering en meer in terme van gelykwaardigheid en wederkerigheid. "This helps us construct a theory of family love that makes equal regard or mutuality central and then makes self-sacrificial love as an essential but subordinate moment of love that is mainly in the service of equal regard" (D Browning et al., From culture wars to common ground: Religion and the American family debate, Louisvale 1997, 22-23).

16 Die strukture en asse in hierdie model is nie direk afgelei vanuit die Skrif nie, maar toon aan die interdissiplinêre verhouding tussen pastoraat en die geesteswetenskappe. In elk geval bestaan daar nie in die Skrif, as sodanig, "'n model" vir gesinsbediening nie. "The Bible is resoundingly unhelpful as a source for model structures and relationships for contemporary families" (S Purvis, "A question of families", Interpretation (Apr 1998), 152).

17 Friedman, $a w, 15$ : "The components do not function according to their 'nature' but according to their position in the network".

18 Friedman, $a w, 24$ : "The most important ramification of homeostasis for family theory is its emphasis on position rather than personality when explaining the emergence of a symptom". 
19 M McGoldrick \& $\mathbf{R}$ Gerson, Genograms in family assessment, New York/London 1985, 9: "The backbone of a genogram is a graphic depiction of how different family members are biologically and legally related to one another from one generation to the next". Vir 'n verdere uiteensetting oor die waarde van grafika in die pastorale gesprek, sien J C Müller, "Grafika as hulpmiddel in die pastorale gesprek", Skrif en Kerk 12/1 (1991), 54-63.

20 Sien die rol van die teologiese faktor soos reeds bespreek. 